Article

\title{
Lux et Tenebris? Coloniality and Anglican Missions in Argentine Patagonia in the Nineteenth Century
}

\author{
Hugo Córdova Quero
}

check for updates

Citation: Córdova Quero, Hugo. 2021. Lux et Tenebris? Coloniality and Anglican Missions in Argentine Patagonia in the Nineteenth Century. Humanities 10: 36. https://doi.org/ 10.3390/h10010036

Received: 10 December 2020

Accepted: 20 February 2021

Published: 25 February 2021

Publisher's Note: MDPI stays neutral with regard to jurisdictional claims in published maps and institutional affiliations.

Copyright: (C) 2021 by the author. Licensee MDPI, Basel, Switzerland. This article is an open access article distributed under the terms and conditions of the Creative Commons Attribution (CC BY) license (https:// creativecommons.org/licenses/by/ $4.0 /)$.
Department of Theology, Starr King School for the Ministry, Oakland, CA 94623, USA; hquero@sksm.edu

\begin{abstract}
Within the modern capitalist World-System, Missionary work was mostly developed through the connubiality with colonial powers. The missionary work of the Anglican Church is no exception. This article centers on the missionary enterprise carried out in Argentine Patagonia in the nineteenth century. Missionaries' reports carefully narrated that venture. However, the language and the notions underlying the missionary work's narration reveal the dominion of colonial ideologies that imbued how religious agents constructed alterity. Connecting the missionaries' worldview with the political context and expansion of the British Empire allows us to unfold the complex intersections of religious, ethnic, racial, and geopolitical discourses that traverse the lives of indigenous peoples in South America.
\end{abstract}

Keywords: Anglican missions; Argentine Patagonia; British Empire; Missionary reports

\section{Introduction}

"Thus, we lived from week to week, seeking according to the grace given to us to be useful in opening the eyes of these poor people to see and follow the light of God's truth, and to love and serve their God and Saviour".

Thomas Bridges (Kirby 1871, pp. 140-41; emphasis mine)

With those words, the Anglican missionary Rev. Thomas Bridges concluded his report to the South American Missionary Society (SAMS) for 1871 (Kirby 1871, pp. 137-41). His report was part of the work carried out by the missionaries in South America, who covered Argentina, Bolivia, Brazil, Chile, Paraguay, Peru, and Uruguay in what later became the "Diocese of Malvinas." According to Martínez (2010):

The Anglican missionaries, as was customary in missionary societies at the end of the nineteenth century, carefully documented their activities ( . . ) by means of letter, reports, drawings, maps, photographs, and other graphic forms, many of them published in the society's monthly magazine (p. 83).

The missionaries understood their work as not only an "evangelizing" but also a "civilizing" endeavor. Thomas Bridges—-the last missionary among the Yagan peoplecontinued the evangelizing enterprise that the Anglican Church began in 1833. The origin of the missionary expeditions coincided precisely with when the Falkland Islands were annexed to the British Empire. The British navy arrived in 1833, one year after the garrison from the Provincias Unidas del Río de la Plata-soon after, Argentina-left their post in 1832 (Graham-Yooll 2002, p. 50). Nonetheless, the British government has long claimed sovereignty of the Falkland Islands over the Spanish Empire's rights. When the independent government of the Provincias Unidas del Río de la Plata protested through its governor, Mariano Moreno, Viscount Palmerston wrote an extensive letter on 8 January 1824, in which he claimed British rights over the islands (Fitz Roy 1839, Appendix to vol. 2, pp. 150-53).

This article explores the history of the Anglican missions in Argentine Patagonia in the nineteenth century and their connection with the British colonial enterprise in the 
region. In a particular way, it seeks to pay attention to the colonialist ideas that infused the construction of otherness in ethno-political terms under the garment of religious piety and mission. At the same time, it addresses the biblical-theological reinterpretations that sustained the notions of "evangelization" and "civilization" that legitimated the dominion of the original peoples of the region as directly connected to the European self-understanding of superiority.

\section{Anglican Missions in Argentine Patagonia}

The missionary work in Argentine Patagonia as well as the Falkland Islands developed through several stages. I will briefly focus on four moments that marked the unfolding of missionary activities amidst the many predicaments the religious agents faced in their attempts to evangelize the native populations.

\subsection{The First Mission with Fitz Roy, Darwin, and Mathews, 1833}

Because the Anglican Church was the form of Christianity adopted by the British Isles since their detachment from Western Christianity in 1539, British colonial territorial expansion in the Tierra del Fuego and Falkland Islands region was soon the focus of Christianizing expansion. The Patagonian and Magellanic regions strongly attracted missionary attention for the Anglican Church for being considered "a virgin field" for evangelization. The place was crossed by the British fleet ships that did not stop there more than necessary, except some English captains who explored some areas. It was precisely the annotations of these captains that fomented the missionary interest of the Anglicans. Thus, the Adventure and Beagle ships ${ }^{1}$ — under the command of Captain Philip Parker King-left England on 22 March 1826 from Plymouth Sound (Parker King 1839, p. xi) to make a map of South America from the Río de la Plata (Argentina) through Tierra del Fuego (Argentina) to Chiloé (Chile).

Robert Fitz Roy was in command of the Beagle as Captain to fulfill his role in the task after the suicide of Captain Pringle Stokes, who shot himself in 1828. Onboard this ship, Fitz Roy anchored off the island in a place they called "Goree Roads" and named the island Lennox (Bridges 1948, p. 29). From there, Fitz Roy sent men to explore the channel, later named after the ship as "Beagle Channel." He returned to England in February 1830, incidentally taking four Fuegian Yagans as hostages. In a letter dated 12 September 1830-written aboard the Beagle at sea to England-Fitz Roy $(1839$, vol. 2, p. 4) explains that the hostages were Fuegia Basket, a nine-year-old girl, York Minster, a twenty-six-year-old boy, Boat Memory, a twenty-year-old boy, and James "Jemmy" Button, a fourteen-year-old teenager. Boat Memory would die in England after being vaccinated against smallpox. These hostages further promoted Anglican missionary motivation, especially after being presented to the royal court in 1831. The missionaries considered them as "civilized," having learned English and adopted Anglican Christianity as their religion (Bridges 1948, p. 30).

Fitz Roy-commanding the Beagle for the second time-and missionary Richard Matthews set sail from Plymouth Sound on 27 December 1831. Fitz Roy chose Charles Darwin as his "traveling companion" as both men shared an affinity for science and expressed his interest in science and religion in his essay on scientific geography and the Bible (Fitz Roy 1839, vol. 2, p. 659). Fitz Roy wrote that essay during that second trip (Darwin [1839] 2018). The second voyage of the Beagle is perhaps the most famous. Onboard this ship, Darwin made the first observations that would later lead him to develop his evolution theory. The three Yagan converts also undertook the journey back to their homeland. In his Voyage of the Beagle, (Darwin [1839] 2018) describes them as follows:

I have not as yet noticed the Fuegians whom we had on board. During the former voyage of the Adventure and Beagle in 1826 to 1830, Captain Fitz Roy seized on a party of natives, as hostages for the loss of a boat, which had been stolen, to the great

1 Officially the name of the British fleet ships is headed by the initials "HMS," which means "Her/His Majesty Ship." In this article, I have chosen not to include this acronym. 
jeopardy of a party employed on the survey; and some of these natives, as well as a child whom he bought for a pearl-button, he took with him to England, determining to educate them and instruct them in religion at his own expense (p. 196).

It is unknown from whom Fitz Roy bought that teenager for a button, given that the four Yagans were hostages. Darwin's impression of the Yagans in his first contact with them on 17 December 1832 also shows how his Europeanizing perspective defined the construction of alterity with these people:

In the morning the Captain sent a party to communicate with the Fuegians. When we came within hail, one of the four natives who were present advanced to receive us, and began to shout most vehemently, wishing to direct us where to land. When we were on shore the party looked rather alarmed, but continued talking and making gestures with great rapidity. It was without exception the most curious and interesting spectacle I ever beheld: I could not have believed how wide was the difference between savage and civilised man: it is greater than between a wild and domesticated animal, inasmuch as in man there is a greater power of improvement. The chief spokesman was old, and appeared to be the head of the family; the three others were powerful young men, about six feet high. The women and children had been sent away. These Fuegians are a very different race from the stunted, miserable wretches farther westward; and they seem closely allied to the famous Patagonians of the Strait of Magellan. Their only garment consists of a mantle made of guanaco skin, with the wool outside: this they wear just thrown over their shoulders, leaving their persons as often exposed as covered. Their skin is of a dirty coppery-red colour (Darwin [1839] 2018, pp. 194-95, emphasis mine).

Matthews' presence led the delegation to found in 1833 the first "Christian" and "civilized" mission in Wulaia, Tierra del Fuego, in the extreme west of Navarino Island. As a missionary, Mathews officiated the first marriage celebrated under the Anglican rite. The spouses were York Minster and Fuegia Basket, whose age difference was notorious. However, the mission only lasted ten days, as the Yagans destroyed the mission, at which point Matthews embarked again on the Beagle bound for the Falkland Islands.

\subsection{The Second Mission of Gardiner, 1851}

Later, "in England, in 1844, Captain Allen Francis Gardiner [born 28 July 1794] founded the Patagonian Mission. On 25 September 1845 she sailed from Liverpool" (Cutts 1990, p. 1). With him, a series of mission attempts in South America was inaugurated, starting from Malvinas and reaching Chile, Bolivia, Paraguay, and North of Argentina.

It is noteworthy that in his mission, Gardiner's goal was to evangelize native peoples. He maintained the philosophy that Latin America-because it was considered Roman Catholic - was already evangelized. Therefore, the mission aimed to convert the natives. Gardiner had visited Argentina in 1841 with his family in another missionary attempt after his missions in Africa and Papua New Guinea had also failed.

Unfortunately, he was unsuccessful in any of the attempts to establish a mission in Argentine Patagonia. Finally, Gardiner and five companions died of starvation in Puerto Español, on the Beagle Channel, in the first days of September 1851. They were unable to establish a definitive mission among the native South Americans.

\subsection{Despard and Bridges' Last Mission, 1859}

Gardiner's death had impressive repercussions in British missionary circles. The Anglican Church continued with Gardiner's work under the supervision of the Rev. George Packenham Despard. It was Despard who finally put into practice what Gardiner advised in his writing "Outline of a plan to conduct future operations in Tierra del Fuego" that he wrote in Puerto Español shortly before his death. There, Gardiner advised establishing the mission base in Malvinas and from there to go to Tierra del Fuego. Therefore, Despard 
urged the missionary society to plan the mission following this advice. In 1854, the missionary schooner "Allen Gardiner" was launched in Dartmouth, which,

(... ) he sailed from Bristol on 24 October 1854, with the necessary personnel. It was not easy to find a captain and sailors who were sincerely religious. W. Parker Snow, who had just retired from the navy, offered as the captain, missionaries included catechist Garland Phillips and surgeon Ellis. They arrived at the place chosen to establish the mission headquarters on 5 February 1855, which was Keppel Island, neighboring the Malvinas, about 22 miles in circumference (the base that was closed on 28 July 1906) (Monti 1969, p. 122).

Despard came to Keppel with his family in August 1856. With him was his 13-year-old godson Thomas Bridges. The Rev. John Funis Ogle, vicar of Flamborough and pillar of the missionary society, also accompanied him. The entourage also included Allen W. Gardiner (son of Captain Gardiner), catechist Charles Turpin, and Mr. W. Bartlett. To consolidate the missionary headquarters in Keppel, Despard made two trips searching for construction materials, which he acquired in Rio de Janeiro, Brazil. He also sought new sailors, which he hired in Montevideo, Uruguay. He finally settled with his family in Keppel in 1858.

On 6 October 1959, an expedition left for Wulaia under the charge of catechist Phillips. They arrived at Navarino Island on November 1 to settle, cultivate the land, record the locals' phonetics, and celebrate worship services on the mainland. For several days, relations were friendly with the locals. On Sunday, 6 November, the missionaries celebrated a worship service, but the indigenous people attacked them. They were all killed. Three years later, in 1862, Despard returned with his family to England.

After Despard's departure, 18-year-old Thomas Bridges decided to stay in charge of the play. Years later, he would become the shepherd who would make Gardiner's dream of establishing a permanent mission among the Onas and Yagans people bear fruit. Regrettably,

( ... ) the hostility of the European [and Argentine settlers; both unrelated to the Anglican Church], and even worse, the diseases they brought with them, ended up undermining any trace of the great work that had begun to bear fruit among the primitive inhabitants of Tierra del Fuego (Cutts 1990, p. 3).

Some scholars may consider Bridges' attitude as "inculturation," that is, the missionaries' intention to learn the language of the "natives" to "speak to them about Christ." However, his vision and treatment were of "civilizing superiority" toward peoples who needed rescuing from their "ignorance" and "barbarism." Perhaps this situation was one reason why they did not achieve a better relationship with the Onas and Yaganes peoples. Instead of imposing such an exogenous form, it might have been better to adapt Anglicanism to those peoples' cultural conditions.

\subsection{Stirling and the Founding of the Diocese of the Falkland Islands}

The Rev. Waite Hockin Stirling succeeded Despard. He left Bristol for the Falkland Islands in August 1862. A new missionary group accompanied him. He made stops in Montevideo (Uruguay) and Buenos Aires and Río Negro (Argentina) during the trip. He left two young missionaries-Francis Naville Lett and John Andrews-in Río Negro. Those two missionaries started the Patagones-Viedma mission. Stirling arrived in Keppel on 30 January 1963. At the same time, Richard S. Cutts (1990) relates:

In 1864 the Patagonian Mission changed its name to the South American Missionary Society (SAMS, in English). In the following years, expanding from Keppel Island, the missionaries carried out their evangelizing work in Tierra del Fuego, [Argentine] Patagonia, and southern Chile (p. 3).

Stirling was the man who extended the vision of the Anglican presence beyond the confines of religion. He legitimized the colonial actions of the navy of the British Empire in the name of God. A quotation writing by him and reproduced in the South American Missionary Magazine by its editor puts this very clearly: 
As I pace up and down at evening before my hut, I fancy myself a sentinelGod's sentinel, I trust-stationed at the southernmost outpost of His great army. A dim touch of heaven surprises my heart with joy, and I forget my loneliness in realizing the privilege of being permitted to stand here in Christ's name (Kirby 1871, p. 136).

Of course, his presence as a Briton in Patagonian territory did not represent a disconnection with the Argentine government. In his diary written for his children, Stirling talks about this business relationship with the Argentine government looking for a place to establish a new Mission building:

The best place I have yet seen is at the eastern entrance of the Beagle Channel, which on the map is seen as a block of land, on the north side, forming the narrows. It is in fact an island, and I call it Gable Island, because of the gable-shaped cliffs which characterized the eastern end of it. This island the Government of Buenos Ayres has granted to the Mission on payment of a silver dollar a-year. But the reason I did not occupy it at once was this, the natives down there have not been so familiarized with our ways as those up here, and are not so trustworthy; secondly, the natives up here would not like to settle down there, unless I could assure them a permanent European establishment, and this I could not do without an iron house; thirdly, the natives belonging to these parts, and their jealousy would only be kept in restraint by their knowing that if they did not tolerate them the missionaries would not stop there, and so on (Kirby 1869, p. 106).

In January 1869, he went to Ushuaia and remained there for seven months without arms. When the missionaries went to look for him in August, they found that Stirling, being in perfect condition, had demonstrated the possibility of a mission there. He then left for England to be ordained at Westminster Abbey on 21 December 1869 as Bishop of the Falkland Islands with jurisdiction over South America. Before leaving, he had put Bartlett in charge of Ushuaia and Resyek from Keppel.

With the founding of the Diocese of the Falkland Islands under the care of Bishop Stirling, the work of the Anglican Church entered a new stage. Hard work also began for Bishop Stirling to keep together in the same Church the two roots that grew and developed during his episcopate. A challenging task due to specific internal differences of the Anglican Church.

On the one hand, they had different visions. While southern Argentina's mission prioritized evangelization, the River Plate chaplaincy's goal was to serve only the British immigrants' community. It did not have a purpose of evangelizing.

It is noteworthy that the first English immigrants arrived at the Río de la Plata after 1810, after the declaration of separation of the Viceroyalty of the River Plate from the Spanish Empire. Many of those immigrants came to work in Argentina for companies that depended on English capital. Concurrently, many of them were faithful to the Church of England. Cutts (1990) states that "the need for their children to be baptized and confirmed, or their marriage solemnized or other forms of pastoral care made them begin to meet informally from 1823" (p. 1) in the living room of the house of Mr. George Frederic Dickson. In 1824, Argentina's government allowed the first office according to the Anglican rite and in the English language. That happened,

as a result of the recognition of Argentine independence by the minister [George] Canning (1 January 1825) and the First Treaty of Friendship and Trade that Argentina signed with a foreign country, on 2 February, entering into force on 12 May (negotiations had begun on 23 July 1824) (Cutts 1990, p. 1).

Article 12 of said treaty guaranteed freedom of conscience and worship to British subjects. John Woodbine Parish communicated that by letter sent to Minister Canning dated 20 October 1825. The letter also expressed that the Rev. John Armstrong-until then, a chaplain in Honduras-would be the chaplain in Buenos Aires (Bisio 1993, p. 2). Rev. Armstrong arrived in 1825 as the first chaplain and took over the pastoral care for British 
immigrants. According to the Anglican rite and in the English language, he supervised the installation of a chapel in the Philharmonic Society hall (Cutts 1990). The celebration of the first service occurred on 25 September 1825 (Monti 1969). After that, the parishioners continued to meet in a house rented to Mr. José M. Coronell, as evidenced by the payment receipts from the archive of the Anglican Cathedral of San Juan Bautista (Bisio 1993, p. 2).

On the other hand, knowing the Church of England's situation, we can deduce that the missionaries in Argentine Patagonia and the immigrant in the River Plate belonged to two different ecclesiastical sectors. In other words, despite the best intentions, the Anglican spread in Argentina reproduced particular ecclesiological and missiological models. For this reason, the southern missions identified with the "evangelical sector" of the Anglican Church, whose main concern was evangelization. That sector is commonly known as "Low Church." The River Plate chaplaincy identified with the "Anglo-Catholic sector." It is usually named "High Church," and their concern was primarily to guarantee chaplaincy.

The missionary efforts in Argentine Patagonia were firm and steady. Bridges, who had traveled to England, returned married to Mary Varder. Their marriage occurred on 5 August 1869. With him came two catechists: James Lewis (also a carpenter) and John Lawrence (a farmer). Bridges' first daughter, Mary, was born in Port Stanley, in the Falkland Islands, on 5 October 1869.

In 1870, Bishop Stirling "visited the Ushuaia mission, baptizing thirty-six indigenous people, adults and children, in an open-air ceremony and before some 150 attendees" (Monti 1969, p. 129). Bridges settled in Ushuaia permanently on 27 September 1871. His son Lucas - the first white man born in Tierra del Fuego-was born, later becoming a missionary in Santa Cruz. Bridges established a small farm with cattle, horses, and birds. The Lewis couple joined him, and the sixteen families living there also joined. Others joined them. With real conversions, the mission prospered to the point that the locals themselves celebrated and conducted their services. In March 1872, Bishop Stirling visited them, and in 1873 new missionaries joined them.

However, the mission disappeared. In June 1884, a census carried out by Bridges yielded 949 Yagan individuals. In 1886, the census returned an alarming count of 397 individuals. That reality led Bridges to submit his resignation from the missionary society in 1887, claiming that it no longer made sense to continue maintaining a mission there, as the native population would inevitably disappear. Bridges left for England, and when he returned with his successor Edwin C. Aspinall, in 1888, he inaugurated the mission of Baylyn Island, near Cape Horn, Tierra del Fuego. Finally, Bridges died in Buenos Aires on 15 July 1898. Currently, there is only one survivor of the Yagans: Cristina Calderón, born in 1924. She is currently ninety-two years old and the last person to be able to speak the language of the Yagans, who lived in Argentine and Chilean Patagonia for six thousand years (Pujals 2014). When she dies, the Yagans will be definitely extinct.

\section{Missionaries and Their Time: Theo(ideo)logies and Mission}

The conceptions that the missionaries expressed in their reports were not impartial. They impacted the way missionaries treated and how they related to their parishioners who had converted to the Christian faith in the form of Anglicanism. Beyond their "good intentions," their actions implied how modern Europe understood and constructed the otherness represented by the mission fields' indigenous peoples. In the (re)reading of the mission reports published in the South American Missionary Society magazine, three connected elements appear that set the colonial tone with which the missionaries approached these peoples. In this section, I briefly analyze those elements to contribute to further understanding and contextualizing the reports.

\subsection{Religious Interpretations}

The Gospel of John uses the word $\varphi \omega \varsigma$ (light) more times than in the other gospels. It is in that gospel where Jesus presented himself as the "light" that breaks into the world

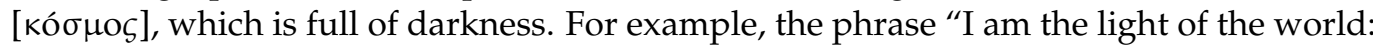


whoever follows me will not walk in lukewarmness, he will have the light of life" (Jn 8.12) pronounced by Jesus affirms this notion. Furthermore, Jesus is not like the light but is the light. Therefore, only he can reveal all things in darkness since human beings " . . . ) love darkness more than light" (Jn 3.19). In the proto-Gnostic basis of the Gospel of John, darkness represents the impossibility for human beings to walk knowing where they are going. That is, when walking in darkness, they err. Hence, the gospel also uses that image to designate the absence of knowledge in Jesus' message.

It is cumbersome that the notion of light/darkness was heavily represented in the Anglican missionaries' writings in Argentine Patagonia in the nineteenth century. Other ideologies conditioned their reading of Christian sacred texts, and that tinged their reports. That is, the missionaries approved a Eurocentric cultural vision in their understandings of biblical themes. The European Renaissance, with its concepts of "civilization" and "barbarism," had already incorporated the binomial "light/daylight-darkness/night," moving them away from their religious roots, as Aurora Egido (2010) affirms:

Identified in the Gospel of Saint John with the Word and converted into a divine symbol of good, the light was homologated with life itself, generated by the ray that pierces opaque bodies. But the so-called Age of Enlightenment moved away from the symbolism of divine omnipresence to place light effects in the territory of the human mind, showing its desire to clarify, elucidate, and illuminate the unknown through the exercise of knowledge. From these assumptions, which had their roots in the Renaissance's humanistic tradition, a broad cultural, political and sociological program was configured that would encompass all spheres of thought and even action at the most diverse levels (p. 10).

This notion of "light" as "civilization" was part of European expansionist pride after the Middle Ages-also known as "the age of darkness" — where "barbarism" had prevailed. That is to say; it was not surprising that the missionary discourses were plagued with that notion. After all, the missionaries were educated and socialized in a Europe advancing over the rest of the world, considering it an object for colonization. Therefore, they saw the Yagans of Argentine Patagonia as "beings" lacking "civilization," "light," "knowledge," and "faith."

\subsection{Racial/Ethnic Constructions}

The religious interpretations coupled with the contemporary notions of race/ethnicity that the missionaries upheld. In fact, the passage from the binomial "light/daylightdarkness/night" to that of "lightness/light skin-darkness/dark skin" was just next door.

The genesis of the term "Caucasian" — that significantly privileges light/white skinhas dramatically defined the West's racial relations throughout modern and contemporary times. That originated in the studies of Johann Friedrich Blumenbach in the 1700s, who modified the notions proposed by his mentor, Carl Linneo (Gould 1994). In his work, Linneo (1758) did not pass judgment regarding the world's peoples' goodness or badness. He just reported on an experiential observation of where the peoples lived and how they acted. That does not mean that Linneo had no judgment, but he intended to describe the world as he saw it, not to foster racial dynamics. Linneo' studies in 1758 draw more on a geographic tone, making sense of the word's peoples concerning their places of residence.

However, Blumenbach (1795) introduced a different notion that transitioned from geography-based observations into subjective valorizations. According to him, the Caucasus River peoples were the most beautiful that he has ever encountered, and therefore they must be superior to other peoples. By doing this small change, he inaugurated the basement for modern notions of race and racism (Gould 1996). That is how the category "Caucasian" came into place within the racial dynamics in the West. It is noteworthy that from a more "circular understanding" of the different peoples of the world as in the studies of Linneo, we progress into a more pyramidal, hierarchical understanding that privileged "Caucasians" as the "best" of humanity as in Blumenbach's studies. From there, society "degenerates" - this is the actual term that Blumenbach used in the 1795 edition of his 
work-into other races. Thus, Blumenbach's work became an essential source of modern racism. However, we cannot forget that the notions of "purity" and "race" were also crucial before the 1700s, as in the Spanish and Portuguese Empires' racial discourses in the Iberian Peninsula (Grosfoguel 2004).

The missionaries saw the world-and the human beings beyond the confines of the boundaries of the European lands-as the concretization of the racial ideology passed to them through their culture. Thus, the dark skin natives of Argentine Patagonia were seen as inferior to the European settlers.

\subsection{Geopolitical Inscriptions of Difference}

Those notions of race/ethnic unbalanced power relations have a precedent in the inscription of the Americas into the emerging modern capitalist World-System. The Americas-as it has been the case with Africa and Asia-were res extensa to be taken.

In taking into account the performative way of that inscription, Walter Mignolo (2006) focuses on ethnicity and territoriality. He shows how the depiction of territories is not only related to ethnicity but also to the way that racial discourses were enacted in the modern, capitalist World-System. In other words, the conception of space is bound to particular ethnic agents who conceived that space in specific ways. In analyzing the case of Father Ricci in Asia, Mignolo (2006) states that:

( ... g) geometric projections seem to have allowed the introduction of a double perspective: first, a dissociation between a center determined geometrically (Rome, Jerusalem, or China) and a center determined geometrically, which does not replace but complements the ethnic one; second, the assumption (so well illustrated by Ricci) that the locus of observation (geometric center) does not disrupt or interfere with the locus of enunciation (ethnic center). It seems obvious to me that, for Ricci, the ethnic center remained in Rome, although geometrically he was able to place the Pacific and China in the center of the map, as if geometry were the warranty of a nonethnic and neutral ordering of the shape of the earth (p. 222).

Mignolo (2006, p. 223) goes further to state that the detachment of geometry from ethnicity transforms the issue into "a matter of political power." For the author, Spanish territoriality repressed coexisting territorialities by mapping "the city, the earth and the cosmos" (Mignolo 2006, p. 226) through ethnic rationalization. In summary, Mignolo (2006) concludes that:

(... ) maps are and are not the territory. They are not, because they do no reflect any essential reality of the shape of the earth or of the cosmos. They are because, once they are accepted, they become a powerful tool for controlling territories, colonizing the mind and imposing themselves on the members of the community using the map as the real territory (p. 237).

The notions of "progress" and "evolution" completed universalizing European ethnocentrism while mapping territories. Those territories could be either earthly or bodily spaces. Mignolo (2006, p. 260) further analyzes the colonization of space by looking at the redistribution of power relations behind the depiction of space/territoriality in inscribing "the Americas on the map." He states that by declaring "the Americas" as such or as Novo Mundo, Europeans assumed that their perspective of the world was genuinely valid and ignored Amerindian cultures' perception. Between 1492 and 1555, the enterprise of co-opting/colonizing "the Americas" evolved into literary devices: maps. Since then-according to Mignolo (2006, p. 267) — the world looks the same. A remarkable contribution is the awareness of colonialism before the classic colonial ideology of the anglo-Saxon world.

The claiming of Europeans to be the first ones in reaching the Americas-and thus taking ownership of the land-ultimately erodes the fact that other peoples have already set foot on the continent's shores. As early as 1312 C.E., King Abubakari II of Malí and a fleet of 200 ships reached Mexico (Van Sertima 1976). Similarly, the Chinese Empire's most 
giant armada full of ambassadors, food, silk, and thousands of sailors navigated the Pacific to disembark in the Americas in 1421 (Menzies 2002).

However, a significant consequence of European colonialism was the erosion and (re)writing of history and the categorization alterity. From 1492 onward, the depictions of non-European cultures/individuals as inferior to European conquerors and explorers became the "norm" (Mignolo 2006, p. 275). The commonly ignored consequence of this process is that Europe constituted itself by opposing non-European worlds. In other words, it was by mirroring itself in those cultures that Europe could construct its understanding of true self. In other words, by exoticizing/degrading Otherness, the European Self emerged as such. Thus, territoriality - or the earth's actual shape-was an excuse to conquer and colonize Otherness (Mignolo 2006, p. 309).

The location of Tierra del Fuego within the British imperial cartography also added another layer to the complex intersectionality of issues surrounding the Anglican missions in Argentinean Patagonia. Although a territory claimed by the Argentine government, the British Empire took the Falkland Islands in 1833 and annexed them to the commonwealth. The missions to Tierra del Fuego comprised a religious motive and the implicit geopolitical advancement of the British Empire in Argentinean lands. The precedent is the invasions carried out in 1806 to Buenos Aires in the River Plate as it was the capital of the River Plate Spaniard Viceroyalty. The invasion failed due to the resilience of Buenos Aires' residents and their troops. That fostered the process of independence of the territories of the River Plate Viceroyalty from the Spanish Empire. That began with the revolution carried out on 25 May 1810, by the Spaniard Viceroy Baltasar Hidalgo de Cisneros, who, along with the residents of Buenos Aires, proclaimed the first independent government in an open cabildo. The process took six years for all the territories within the former viceroyalty to join the decision. The representative of the Provincias Unidas del Río de la Plata (United States of the River Plate) declared independence from Spain on 9 July 1816.

By the time the British Navy claimed territories in the south of the former viceroyalty, the Argentinean government was already an independent nation, sovereign over the regions that they claimed for the Crown, such as the Falkland Islands. Missionaries and military men from the British Empire never recognized that situation in the Argentine Patagonia, a difference with their counterparts in the River Plate that signed a treaty and got official concessions for the practice of their particular way of Christianity: Anglicanism.

\section{Missions and Colonial Imaginaries of Alterity}

Although colonial, the perceptions of native populations' religious "evangelization" were similar between Roman Catholicism and Anglicanism. Latin America suffered twofold colonization. On the one hand, the peoples and the land were conquered with "the cross and the sword," that is, the collaboration between the political powers exercising power over the conquered peoples with the legitimation of the spiritual power, i.e., Christianity. On the other hand, from the standpoint of Roman Catholicism, the conquistadores classified the gods of the conquered peoples as "demonic" while deemed their beliefs as "superstitions." The arrival of Anglicanism to Argentine Patagonia did not bring a different perspective. For the Anglican missionaries, the religions among the Yagans were not valuable. They assumed that those religions did not proceed from the supremacy of Christianity's particular Anglican experience. Overall, their understanding of Christianity never allowed the missionaries to recognize Yagan spirituality as equal or respect their culture.

It is uncertain to know what degree of influence the "evangelizing" and "civilizing" endeavors of the Anglican missionaries had among the Yagan communities. Possibly their impact achieved an alternative place, the third space of hybridity, something similar to what occurred among the people evangelized by Roman Catholics who developed popular piety heavily drawing from their ancestral religions (Espin 1997). Certainly, that might not be appreciated by the European colonizing mentality. A consequence of that mentality implied that the Western agents saw themselves as "pure" while the Other always remained as "impure," hybrid, mixed. Thus, considering hybridity as unfavorable. For Bhabha (1996, 
2004), hybridity is a place of enunciation as well as cultural exchange. However, in the colonial performativity, that space of hybridity has been the place where colonial power is expressed over the colonized subjects. In other words, by naming the Other as a hybrid, the Other is re-located in an inferior position compared to the colonizer, and that masked the "whitewashing" of colonial dependency. Still, the colonizer always re-locates itself in a position of superiority. What is clear from this is that the West cannot exist without the Orient as the Western self's superiority cannot be showed and recognized without subsuming the Other into a lesser category, close to sub-human (Córdova Quero 2015; Córdova Quero and Torchiaro 2020). In the particular case of the spirituality and religions of peoples worldwide, the colonial performativity of power rendered them inferior or contrary to the Christian norm. That dynamic was at the horizon of the Yagans' faith's characterization, which suffered the same fate.

However, the colonizer and the colonized individuals and communities are not separate compartments but symbiotic. There is a relationality between both. We cannot understand it without paying attention to its dialectic because the colonizer's identity arises in opposition to the colonized construction. That is where the contribution of Frantz Fanon (Fanon [1961] 1963) is necessary. For him, there is an interconnection between colonizer and colonized. Fanon explains that colonized individuals and communities form their identity in the dialectic of this colonial relationality. To mark Christianity's superiority in bringing the faith that would offer salvation and civilization to the Yagans, their spirituality needed to disappear. There are no narratives that would explain the ritual or ceremonies that the Yagans practiced. All the accounts praise how the "noble missionaries" were making all efforts to spread the "good news" of Christianity to the Yagans. In doing so, the missionaries constantly reified the prominence of Christianity over the spiritualities of the Yagans.

Furthermore, the British Empire did not consider the Yagans as part of the Latin American heritage tied to the Spanish or Portuguese Empires. Therefore, they sadly were forced to embrace a religion such as Christianity. Although without the use of swords but certainly with the help of firearms, that process paralleled how other aboriginal peoples in Latin America were forced and coerced to embrace Christianity.

We must not forget that when the Anglican missionaries established their "civilizing" and "Christianizing" missions in Argentine Patagonia, there were also disturbing events in the rest of Argentina. With the excuse of "civilizing" the native populations - the Argentinean government—carried out military campaigns for eradicating the "barbarism" represented by the native peoples. Both the work of Domingo F. Sarmiento, especially his book Civilización y Barbarie (civilization and barbarism) (1845), and the terrible effects of the "conquest of the desert" campaign carried out by Julio Argentino Roca between 1878 and 1885 were echoes of these colonialist ideas. The genocide consummated from 1820 to 1885 by successive Argentine governments against Patagonia Argentina's original peoples managed to notably decimate the population due to the greedy programs of agriculture exploration and exploitation of their aboriginal lands (Halperin Donghi 2005). In the Anglican missions, the Yagans, although many died from firearms, ended up disappearing because of diseases brought by missionaries, sailors, and settlers.

In that regard, it is shocking that Stephen Neill (1982) celebrates the connubial of colonialism and missions when he affirms:

It has to be remembered that in the nineteenth century the alternatives for many peoples were not independence and enslavement, but total destruction (by unscrupulous exploiters or through the slave-trade) and the possibility of survival in a state of colonial dependence. In many areas the European powers found the peoples divided, poor, and barbarous, and left them united, prosperous, and well on their way to taking their place in the councils of the nations of the world (p. 249).

However, Said [1978] (Said [1978] 1979, pp. 67, 100) challenges that "positive perception" with a somewhat different vision, which is the relation between Christianity and the 
imperialist ideology through missions, something that is also supported by the analysis of Piu-Lan Kwok (2001, p. 51), specifically for the case of the Anglican missions.

\section{Conclusions}

Colonialism has played a predominant role for the last five hundred years in molding different cultures through the Christian missions and their "evangelization." The connubiality of colonialism and religion has notoriously changed cultures. Former colonial powers may have changed their mentality, but their ex-colonies still have to deal with that colonial history and the cultural damage suffered from that past. The former colonies still have to re-do their history to find their ways to deal nowadays with something imposed on them while recovering the pre-colonial past that was erased or hidden from them. I found that a bit unfair. That is the hope in better cases. In the case of the Yagans of Tierra del Fuego, there is no one left to do that decolonization in Argentine Patagonia.

Former colonial powers expect too much from the former colonies when they-the colonial powers - set their terrible dynamics of cataloging otherness in motion. Colonialism almost always displayed the exotic, oriental gaze. In other words, the colonial rulers saw the different cultures and other races as something "exotic," which is a more objectifying colonial performativity. That utters ethnic and racial othering features because many individuals and communities become "the exotic" or "the fetishized" other. Thus, they were placed in a second-class status. Othering also entitles seeds of discrimination and oppression built historically and philosophically over the centuries to understand/(re)construct the Other/s as "immature" and, consequently, as deserving to be ruled. By considering the Yagans as immersed in "barbarian darkness," the missionaries justified their actions of aiding the British Empire to claim ownership over their territories far away from the colonial metropole. With their particular understanding of Christianity and "the ways of England as the ways of the world," they could not see any positive feature in the Yagans. The missionaries straightforwardly imposed upon them their Anglo-Saxon ways under the garment of Anglicanism to enact "civilization." The consequence was the complete obliteration of the Yagans as an ethnic group as well as their culture.

The emergence of hegemonic religious discourses among the missionaries accompanied - even today - continued ways to justify economic exploitation and the dismay of local cultural practices. We observed those dynamics at various geopolitical levels-local, national, and international-traversed by colonialist performativities prevailing in the past and present of the modern, capitalist World-System. The missionaries teamed with the imperial forces of Great Britain to annex and dominate lands across the globe. In their reports printed in the South American Missionary Society Magazine, they justified their presence as "God's calling" to bring salvation to those who- they understood-did not have any faith. However, the reality resulted in many cases of oppression and more devastation than before the colonial forces' arrival. While aiming to bring "the light of Christ," the missionaries" colonial mentality saw the Yagans as "objects" in the "civilizing project" while failing to recognize their disruptive presence amidst their lands and lives.

Funding: This research received no external funding.

Conflicts of Interest: The authors declare no conflict of interest.

\section{References}

Bhabha, Homi K. 1996. Culture's In-Between. In Questions of Cultural Identity. Edited by Stuart Hall and Paul Du Gay. London: Sage, pp. 53-60.

Bhabha, Homi K. 2004. The Location of Culture. Abingdon: Routledge.

Bisio, Carlos A. 1993. La Iglesia Episcopal Británica en Buenos Aires. Indice Documental 1 (1804-1852). Ciudad Autónoma de Buenos Aires: Instituto Bibliográfico "Antonio Zinny".

Blumenbach, Johann Fiedrich. 1795. De Generis Humani Varietate Nativa [on the Natural Variety of Humankind]. Göttingen: Vandenhoek and Ruprecht.

Bridges, E. Lucas. 1948. Uttermost Part of the Earth. London: Hodder and Stoughton. 
Córdova Quero, Hugo. 2015. Coming of Age: A (Post)Colonial and Queer Contribution Towards the Deconstruction of the Notion of 'Minority'. Perspectivas Internacionales. Revista de Ciencia Politica y Relaciones Internacionales 10: 123-52.

Córdova Quero, Hugo, and Belén Torchiaro. 2020. De orientalismos y occidentalismos: Porosidades trans/decoloniales desde las miradasde Franz Fanon, Edward W. Said y Hassan Hanafi. Horizontes Decoloniales 6: 15-68. [CrossRef]

Cutts, Ricardo S. 1990. Breve historia de la Iglesia Anglicana en Argentina. Ciudad Autónoma de Buenos Aires: Diócesis Anglicana de Argentina.

Darwin, Charles. 2018. The Voyage of the Beagle: Journal of Researches into the Natural History and Geology of the Countries Visited during the Voyage round the World of H.M.S. Beagle under the Command of Captain Fitz Roy, R.N. London: Global Grey Books. First published 1839.

Egido, Aurora. 2010. La razón de las luces. In La luz de la razón: Literatura y cultura del siglo XVIII. A la memoria de Ernest Lluch. Edited by Aurora Egido and Jose Enrique Laplana. Zaragoza: Institución “Fernando el Católico", pp. 9-12.

Espin, Orlando O. 1997. The Faith of the People: Theological Reflections on Popular Catholicism. Maryknoll: Orbis Books.

Fanon, Franz. 1963. The Wretched of Earth. Translated by Constance Farrington. New York: Grove Press. First published 1961.

Fitz Roy, Robert. 1839. Narrative of the Surveying Voyages of His Majesty's Ships Adventure and Beagle Between the Years 1826 and 1836 , Describing their Examination of the Southern Shores of South America and the Beagle's Circumnavigation of the Globe. vol. 2 and Appendix to vol. 2. London: Henry Colburn.

Gould, Stephen Jay. 1994. “The Geometer of Race.” Discover (November). Available online: http://discovermagazine.com/1994/nov/ thegeometerofrac441 (accessed on 25 November 2020).

Gould, Stephen Jay. 1996. The Mismeasure of Man. NewYork: Norton.

Graham-Yooll, Andrew. 2002. Imperial Skirmishes: War and Gunboat Diplomacy in Latin America. Oxford: Signal Books Limited.

Grosfoguel, Ramón. 2004. Race and Ethnicity or Racialized Ethnicities? Identities within Global Coloniality. Ethnicities 4: 315-36. [CrossRef]

Halperin Donghi, Tulio. 2005. Una Nación para el Desierto Argentino. Ciudad Autónoma de Buenos Aires: Prometeo.

Kirby, Walter, ed. 1869. Extracts from the Rev. W. H. Stirling's Journal to his Children. South American Missionary Magazine, July 1, 105-12.

Kirby, Walter, ed. 1871. Extract of a Letter from the Rev. Thomas Bridges, Stanley, 19 February 1871. South American Missionary Magazine, November 1, vol. 5, 137-41.

Kwok, Pui-Lan. 2001. The Legacy of Cultural Hegemony in the Anglican Church. In Beyond Colonial Anglicanism: The Anglican Communion in the Twenty-First Century. Edited by Ian T. Douglas and Pui-Lan Kwok. New York: Church Publishing Incorporated, pp. $47-70$.

Linneo, Carl. 1758. Systema Naturæ per Regna tria Naturæ, Secundum Classes, Ordines, Genera, Species, cum Characteribus, Differentiis, Synonymis, Locis [System of Nature through the Three Kingdoms of Nature, according to Classes, Orders, Genera and Species, with Characters, Differences, Synonyms, Places]. Holmiæ: Salvius.

Martínez, Alejandro. 2010. Evangelization, Visual Technologies, and Indigenous Responses: The South American Missionary Society in the Paraguayan Chaco. International Bulletin of Missionary Research 34: 83-86. [CrossRef]

Menzies, Gavin. 2002. 1421: The Year China Discovered the World. London: Bantam Books.

Mignolo, Walter D. 2006. The Darker Side of the Renaissance: Literacy, Territoriality and Colonization. Ann Harbor: University of Michigan Press.

Monti, Daniel P. 1969. Presencia del protestantismo en el Río de la Plata durante el siglo XIX. Ciudad Autónoma de Buenos Aires: La Aurora.

Neill, Stephen. 1982. A History of Christian Missions. Middlesex: Penguin Books.

Parker King, Philip. 1839. Narrative of the Surveying Voyages of His Majesty's Ships Adventure and Beagle Between the Years 1826 and 1836 , Describing their Examination of the Southern Shores of South America and the Beagle's Circumnavigation of the Globe, Volume 1. London: Henry Colburn.

Pujals, Joaquim M. 2014. La última yámana. El País (Madrid), September 1. Available online: https://elpais.com/elpais/2014/07/31 /planeta_futuro/1406816310_738367.html (accessed on 25 November 2020).

Said, Edward W. 1979. Orientalism. New York: Vintage Books. First published 1978.

Van Sertima, Ivan. 1976. They Came Before Columbus: The African Presence in Ancient America. New York: Random House. 